This PDF is a selection from an out-of-print volume from the National Bureau of Economic Research

Volume Title: The Role of Direct and Indirect Taxes in the Federal Reserve System

Volume Author/Editor: NBER and The Brookings Institution

Volume Publisher: Princeton University Press

Volume ISBN: 0-87014-469-3

Volume URL: http://www.nber.org/books/unkn64-4

Publication Date: 1964

Chapter Title: Summary of Conference Discussion

Chapter Author: Samuel B. Chase, Jr.

Chapter URL: http://www.nber.org/chapters/c1877

Chapter pages in book: (p. 295 - 313) 


\title{
Summary of Conference Discussion
}

\author{
SAMUEL B. CHASE, JR. \\ UNIVERSITY OF MARYLAND
}

DURING the past several years, considerable support has been given the notion that the federal tax structure is too heavily weighted with direct taxes. This conference was concerned with a broad range of questions relating to the effects of shifting the federal tax structure in the direction of greater reliance on indirect taxation as opposed to taxation of individual and corporation incomes. Particular attention was focused on the implications of such a shift for resource allocation, tax equity, the rate of economic growth, the pattern of international trade and the balance of payments, tax administration and compliance, and intergovernmental fiscal relations. European experience, often cited by those who favor greater reliance on indirect taxes, was considered in some detail.

This summary presents brief outlines of major points raised in the principal papers together with summaries of the highlights of the open discussion sessions.

\section{Welfare and Growth}

Harberger's paper focuses on the comparative welfare costs, or excess burdens, of direct and indirect taxes. Part of his analysis concerns choices between work and leisure and between savings and consumption. Drawing on the conclusions of this analysis, Harberger considers the effects of alternative tax structures on the rate of economic growth.

Since both income and excise taxes affect the work-leisure choice, Harberger finds that there is no a priori theoretical case in favor of direct taxation. He holds, however, that excise taxes which are not very general, and are imposed at relatively high rates on commodities for which the elasticities of demand are relatively high, will involve more excess burdens than will income taxes of equal yield.

With respect to the savings-consumption choice, Harberger finds that income taxation reduces the rate of saving more than would a consumption tax of equal yield. He argues, however, that the welfare costs stemming from the present differential income tax treatment of different kinds of capital income (under the corporation income tax) are sub- 
stantially greater than the welfare costs arising from the influence of the tax on the rate of saving.

Harberger concludes that the effect of taxation on the labor-leisure choice is of negligible consequence for the economy's growth rate, but that the effect on the savings-consumption choice may reduce the economy's annual growth rate by as much as one-tenth or two-tenths of a percentage point. Citing research done at Chicago, however, he argues that marginal changes in the rate of investment do not significantly affect the extent to which technical progress is "embodied" in capital formation.

Brown, in his discussion of Harberger's paper, points out that marginal rates of transformation and of substitution may be unequal for many reasons other than the differential effects of taxes, so that a change in taxes that would entail welfare losses in a setting of ideal equilibrium could, in the real world, yield a welfare gain, bringing marginal rates of substitution and transformation closer together. In any event, he argues, the proper objective of policy is to equate marginal social costs and benefits. Since private costs and benefits need not reflect their social equivalents, certain tax-induced distortions in private resource use would conform more closely with social aims than complete neutrality.

In the measurement of welfare costs of taxes as they affect the savingsconsumption choice, Brown argues that the relevant comparison is between present values of alternative lifetime consumption patterns, using the after-tax rate of interest for discounting.

Brown agrees that a shift in the direction of more indirect taxation would have a minor effect on the rate of growth if the distribution of tax burdens were unaltered. He questions, however, the realism of assuming that income distribution will not be affected. Brown contends that the major support for a shift toward more indirect taxation derives precisely from the expectation of altering the distribution of income after tax. Once such redistribution is allowed for, it is probable that the shift will raise the rate of saving at full employment.

Fellner contends that Harberger's assumption of full employment is ambiguous because the means by which full employment comes about are not specified. Comparisons of excise and income taxes with equal yields are not necessarily relevant, since some taxes repress private demands less than others.

Fellner points out that recent advocacy of greater emphasis on indirect taxes has rested on arguments not directly considered by Harberger. Pointing out that all taxes except lump-sum levies involve excess 
burdens because they alter resource uses, he contends that imposition of sales taxes on nonnecessities changes economic decisions in a direction that is consistent with avowed policy objectives. Although ideal income taxes involve less excess burden than excises, it is not obvious that such ideal taxes can be enacted, and the taxation of income in this country falls well short of the ideal. In practice, then, greater reliance on excise taxes may strengthen the tax system in terms of equity and efficiency.

Fellner expresses skepticism over Harberger's analysis of the workleisure choice because the findings hinge partly on "guesses" of the elasticity of supply of labor with respect to real wages. If the guesses are altered within a range of reasonable uncertainty, rather different results will be obtained. Fellner also questions Harberger's conclusion about the effect of greater saving on the growth rate, because raising the rate of large-scale investment may yield important external effects, neglected by Harberger, through encouraging a fuller exploitation of innovations.

In the general discussion, Harberger's estimates of the welfare loss stemming from a system of partial excises provoked considerable debate, demonstrating once again that the welfare aspects of taxation are not settled doctrine. Several discussants doubted the accuracy of Harberger's "triangle" measure of excess burden. The triangle in question has an area equal to one-half the amount of tax per unit times the taxinduced reduction in the number of units of output of the taxed good. This triangle, assumed to measure the difference between the integrals of the demand curve and the cost curve (assumed to be horizontal) over the distance between before-tax and after-tax rates of consumption, represents foregone consumer surplus.

It was pointed out that the assumption embodied in the triangle approach - that the demand curve is a straight line over the range in question-is not necessarily correct. If the demand curve were convex to the origin, the welfare loss would be overstated (and if it were concave, the loss would be understated) by the area of Harberger's triangle. Defenders of the triangle approximation argued that for a relatively small tax the criticism had little validity, since over any short interval a demand curve is likely to have something close to a straight-line configuration. The basis for this argument is that a demand curve must have a very curious shape if it is to bend sharply over a small part of its range.

More fundamentally, the validity of Harberger's entire approach was questioned on grounds familiar to those who have followed the postwar 
literature on excise-tax theory. First, the propriety of making the required interpersonal comparisons of utility was questioned. But further, even if these interpersonal comparisons are accepted, introduction of an excise tax necessarily reduces welfare only if all prices are optimal before the tax is imposed. Since this condition is not likely to be found in any real situation, imposition of excises may cause a move either toward or away from the optimum.

In its strongest form, criticism of Harberger's analysis asserted that for all an economist can tell, one point on the production frontier is just as "good" as any other point. A movement along the frontier caused by excise taxation simply means that those who consume relatively more of the taxed commodity are worse off while those who consume relatively more of untaxed commodities are better off, the net gain or loss in welfare being unmeasurable.

The Harberger thesis was defended with the argument that such an agnostic approach makes prescriptive economic analysis impossible. Rather, economists should push for elimination of all distortions of the pricing mechanism, wherever they are found, unless the distortions can be justified on positive grounds. Any change that reduces differences between marginal rates of substitution and transformation is likely to be a change for the better.

Finally, Harberger's constant-cost assumption rules out consideration of the impact of excise taxation on relative factor prices and incomes. This assumption bothered persons who believe that productive resources are rather highly specialized to particular uses, so that any reshuffling of the product mix implies a significant reduction in relative income shares of resources used heavily in production of the taxed commodity. Harberger pointed out that the assumption was made partly to facilitate exposition of the basic ideas, but that it was not a necessary assumption for the analysis. Some discussants, who ventured the guess that resource specialization is not in fact very important, agreed with Harberger's focus on the readjustment of product prices and his attendant neglect of induced changes in factor prices.

Harberger's empirical propositions about the effect of income taxes on output through distortion of the work-leisure choice were questioned. For one thing, his assumption that a change in labor hours has had in the past, and would have in the future, a proportional effect on output did not agree with the views of one discussant whose own feeling, based on a somewhat different interpretation of the historical record, was that 298 
output responds somewhat less than proportionately to a change in hours worked. Additionally, it was questioned whether workers are really able to control the decision as to hours worked, at least to the point of making a small adjustment in response to relatively minor tax changes.

Harberger responded that the intent of his argument had been to indicate that under any plausible assumptions about the nature of the labor-leisure choice and its output implications, the effect of income taxation would be small, so that substitution of excise taxes (which themselves would also have some effect on this choice) could hardly be justified on welfare or efficiency grounds. All in all, the group seemed to accept Harberger's conclusion that two taxes with the same distributional effects, one an excise and the other an income levy, would not have significantly different effects on the labor-leisure choice.

A closely related issue is the effect of consumption taxation on the rate of saving. Those who argued that a shift by the federal government from direct to indirect taxes would inevitably reduce the over-all progressivity of the tax system also envisaged a rise in the full employment level of saving due to the increase in incomes of persons with high marginal propensities to save. This view was not, of course, accepted by those who denied the inevitability of reducing progression by shifting to more indirect taxation.

It was generally agreed that a shift to consumption taxes would make savers better off relative to consumers, since consumption taxes do not tax interest when it is earned.

In response to questions, Harberger elaborated his argument that variations in the rate of capital formation produce only minor variations in the growth rate. It had been asked whether this implied that a zero (or negative) rate of investment was compatible with a positive rate of growth. Harberger replied that it did not. He ventured the view that the highest-priority investments, those that would be undertaken even at very high interest rates, do in fact embody the fruits of technological advance. But such investment opportunities are relatively rare, and the bulk of lower-yielding outlets available at a normal rate of capital formation do not embody technological gains to any significant extent. Therefore, only if investment is retrenched severely will the gains from embodiment be lost. In other words, a relatively low rate of investment, confined to a few high-priority needs, is sufficient to yield most of the fruits of technological advance, making the over-all rate of productivity increase rather insensitive to most fluctuations in the rate of investment. 


\section{Allocation Aspects}

Musgrave and Richman deal in their paper with the effects of a shift from the corporate profits tax to a value-added tax of either the income or consumption variety. They concentrate on questions of resource allocation, international commodity flows, and the balance of payments. In general the authors provide two solutions for every problem considered: one on the assumption that the corporate profits tax is shifted and a second on the assumption that it is not. The shifting in question is "short-run shifting," which involves tax-induced increases of administered prices sufficient to prevent any incursion of the tax into the net rate of return on corporate capital. Such shifting is assumed to take place, if at all, only in the case of products sold domestically.

If the corporate profits tax is not shifted, substitution of a value-added tax of the income type, applicable to all production, will transfer tax burdens regressively (away from profits and onto wages), raise investment incentives, and, possibly, reduce excess burden. If, however, the corporation profits tax is shifted, such a substitution would not bring a significant change in the over-all progressivity of the tax system, nor would it do much to enhance investment incentives. It would, however, reduce excess burden by eliminating the effects of the profits tax on relative prices of corporate and noncorporate products.

A value-added tax of the consumption variety, if substituted for a nonshifted corporate profits tax, will provide an even greater investment stimulus than would a change to a value-added tax of the income type. If the profits tax is shifted, substitution of a value-added tax on consumption items only will again increase incentives to invest. In either case, a value-added tax on consumption will favor savers when compared with a value-added tax of the income variety.

The international implications of replacing the corporate income levy with a value-added tax also hinge on assumptions as to shifting. Furthermore, the results depend on the degree to which resources are mobile internationally.

A tax on corporate profits which cannot be shifted in the short run will distort international resource allocation if capital can move internationally to avoid the tax. This result is avoided if income to capital is taxed at rates prevailing in the country of residence of the owner rather than at the rates of the country in which it is employed ("country of activity"). Although taxes on income to capital-whether by country-of- 
residence or country-of-activity rates-have no direct distorting effect on commodity flows, they may indirectly affect the volume and direction of commodity trade.

A value-added tax of the income type, provided it has an export rebate and compensating import tax provision, does not distort commodity flows, but it may distort resource allocation. This is because such a tax bears partly on income to capital, which may be more mobile internationally than other resources. A value-added tax of the consumption variety avoids this possible defect because income to capital is not taxed.

Substituting a value-added tax for a corporation profits tax will reduce capital exports and increase capital imports if the corporation income tax is not shifted, since net rates of return to corporate capital will increase. If domestic prices rise in response to the change, the allocation of capital between domestic and export industries will be unaffected; but if domestic prices, inclusive of tax, do not rise, capital will be moved into export- and import-competing industries. On balance, it is held, exports will rise and imports will fall if the domestic price level is unchanged; but if the domestic price level rises by the amount of the tax, the change will have no short-run effects on trade.

If the profits tax is shifted, the change from a profits tax to a valueadded tax of the income type, with export rebates and compensating import taxes, will have favorable effects on the trade account but only minor effects on the capital account. The substitution will shift domestic capital to export industries but will have little effect on international capital flows.

If the profits tax were retained but an export rebate and compensating import tax were instituted, exports would be encouraged because capital could escape the tax in export industries, and imports would be discouraged because their prices would rise.

In the light of their analysis, and considering the competing objectives of tax policy, the authors oppose substituting a value-added tax of the income type for the present corporation income tax.

In his discussion paper, Shoup holds that the most useful distinction to make between direct and indirect taxes is that direct taxes can be "personalized" or tailored to the particular economic and social characteristics of the household being taxed, whereas indirect taxes cannot be so tailored. From this point of view the common distinction which equates direct taxation with income taxation and indirect taxation with consumption taxation is not useful or correct. 
Shoup points out that the presumption that the U.S. corporation income tax entails an excess burden may be incorrect. The preferential tax treatment of capital gains that arise from retention of corporate earnings may make the combined corporation and individual levies on profits from corporate activity less than the tax on noncorporate earnings.

Krause, in his discussion paper, contends that substitution of a valueadded tax for the corporation income tax will improve the U.S. balance of payments whether the income tax is shifted or not. If it is not shifted, the improvement will show up on capital account; if it is shifted, the current account balance will increase. Krause criticizes the MusgraveRichman policy prescriptions on the ground that the question of shifting, shown earlier in the paper to be crucial, is ignored in the policy conclusions section. Furthermore, he eontends, it is not proper to reject a change in taxes on the ground that it amounts to tax dumping, since under fixed exchange rates and an inadequate international monetary mechanism, any kind of corrective action by a deficit country must either conflict with liberal international trade policies or involve intolerable domestic contraction. Thus, adjustment of indirect tax rates should be viewed as a possible substitute for flexible exchange rates in correcting international imbalances without forcing domestic contraction.

In the general discussion, the short-run shifting process envisaged in the Musgrave-Richman paper for the corporate profits tax was challenged as not really applicable. Even if short-run shifting is attempted through increases of administered prices, it does not produce an equilibrium that can be maintained. The rise in prices must lead to reduced sales of corporate products; and resources, particularly capital, will be pushed into noncorporate lines. The net after-tax return to capital in both corporate and noncorporate uses will fall, and an excess burden arising from the tax-induced disparity of pretax returns to capital may fall on product buyers.

The further question arose whether, given the Musgrave-Richman view of short-run shifting of the corporation income tax, it is reasonable to assume that "deshifting" would occur if the tax were lowered. At best, in one person's view, this might happen slowly if at all so that substitution of a value-added tax for the corporate income levy might simply result in still higher prices. Such gains might either finance additional capital formation or be captured by labor unions via stiffer bargaining demands.

The shifting aspects of a value-added tax were also questioned. Fear 
was expressed that imposition of a perfectly general value-added tax might not have the neutral impact on relative prices and relative income shares assumed in much of the Musgrave-Richman treatment. In particular, the tax might be shifted forward in areas where labor and management administer prices, but backward in other areas, especially agriculture.

Discussion of the important issue of effects on the balance of payments centered around the question of introducing a value-added tax of the income type in place of the corporation income tax or some part of it. Again, the Musgrave-Richman assumption that a value-added tax engenders uniform price increases was questioned. In fact, it was argued, if the corporation income tax is not shifted, substitution of a value-added tax would logically raise prices by less than the full percentage of the tax, since no markup would be applied to at least that part of costs included in the definition of taxable corporate income. In this case, substitution of a value-added tax with export rebate for the profits tax would lower U.S. prices to foreigners and bring an increase in the net trade balance.

In one view, the imposition of a value-added tax of, say, 7 per cent, in place of the present U.S. corporation income tax, would raise marginal cost curves by 7 per cent and would therefore raise prices by just that amount. But this did not directly meet the argument that under conditions of nonshiftability of the corporate tax, after-tax profits are a residual not subject to "markup." A somewhat different defense of the Musgrave-Richman conclusion was that if the costs of hired inputs rise by 7 per cent, product prices must rise equally to maintain the equality of marginal value product and price at full employment. This, of course, raises the question of whether effects on the employment level would in fact be offset by fiscal and monetary policies.

There was general acceptance of the view that money wages in this country are inflexible downward, so that imposition of a value-added tax would engender pressures for markup. A possibly important qualification to the full-markup thesis was advanced, however. The rate of increase in money wages might be dampened by imposing a value-added tax, so that through time the tax would absorb gains that would otherwise have gone to labor as increased wages.

One person argued that even if wages are completely inflexible downward, substitution of a value-added tax for the corporation income levy might not raise prices at all. If the timing of the change were managed so that total cash payments of tax by corporations were not altered, prices need not be affected. This view discounts entirely the importance 
of the kind of tax being levied, treating all taxes alike as a blanket element of cost subject to markup. Such a complete dismissal of the structural aspects of taxation was of course disputed.

The argument that unequal rates of tax on corporation income distort the international allocation of resources unless offset by export rebates raised several questions. It was submitted that even if all countries taxed profits at the same rate, the proportions of corporate to noncorporate exports might differ considerably, and the neutrality condition would not be fulfilled. A closer approximation to neutrality might be achieved by lowering corporate income tax rates in countries where exports were more heavily weighted with products of corporations. There developed, at this point, some difference of opinion as to whether U.S. exports are more heavily weighted with corporate products than the average of the rest of the world.

A second criticism of the argument that unequal profits tax rates are nonneutral related to use of the proceeds of corporate taxation. The Musgrave-Richman discussion of the possible usefulness of value-added taxes as benefit levies was recalled, and it was pointed out that corporate income taxes, too, might be considered benefit levies in some cases. Suppose, it was argued, that two countries impose corporate profits taxes, one at 50 per cent and the other at 25 per cent, and that both use the proceeds entirely to finance worker pensions which are substitutes for wages. In this case, neutrality would be served by leaving things as they are, rather than by attempting to compensate for the differential through some sort of rebate system.

Moreover, the relevance of comparing tax structures in different countries through the "snapshot technique" was challenged on the ground that the snapshot should also include exchange rates, which have in part been shaped by the impact of tax structures on trade relationships.

The case for substitution of a value-added tax with export rebates and compensating import duties for the corporation income tax was a matter of some disagreement, because of the multiple uncertainties concerning the effect on domestic prices. The suggestion that export rebates and compensating import taxes are justified only to the extent that a valueadded tax leads to an increase in the domestic price level (with the support of monetary policy) was held by one discussant to raise a question whose answer could never be known. He concluded that the only workable course is to treat monetary policy as an independent variable.

It was also argued that, though rebating value-added taxes might be 
logically neater, the international trade implications differ little from those of rebating some part of the present corporate profits tax paid by firms producing exports. Therefore, the latter course, which does not require such drastic revision of the present tax structure, should be considered seriously as an alternative.

The administrative feasibility of exempting exports from value-added taxes was questioned. Since most firms produce multiple lines for sale in different markets, and since most goods pass through several stages of production, it would seem difficult to set up a rebate system that has the desired effects. It was pointed out that the French handle such problems by levying a tentative tax on the gross receipts of every firm, and then grant credit against tax for all taxes levied at earlier stages and shown on invoices. Under this plan, exemption of particular commodities can be simply achieved by exempting eligible sales from tentative grossreceipts tax at the final stage, while still granting the credit for all taxes paid at prior stages. At least under ideal conditions, the market mechanism would bring about the practical result of removing the effect of the tax on exempt goods, from first to final stage. This system would require cash rebates to firms whose tentative tax on nonexempt sales was less than their credit for taxes paid at previous stages.

\section{Equity Aspects}

Eldridge's paper deals with the effects of a shift from direct to indirect taxes on the over-all equity of the tax system, on costs of compliance and administration, and on intergovernmental fiscal relations. His conclusions with respect to equity depend upon comparison of the distribution of tax burdens of different tax forms yielding equal revenues.

Eldridge contends that considerably greater certainty attaches to the distribution of individual income tax burdens than to indirect tax burdens. Accordingly, greater reliance on indirect taxes implies use of a much cruder and less reliable method for achieving tax equity. The assumption that indirect tax burdens can be allocated wholly to consumers (and therefore are borne in proportion to consumption of taxed items) implies that all of the significant effects of a shift from income to excise or sales taxes are found in the readjustment of prices of final products. In fact, important readjustments of factor prices may also occur, and these must be considered in any discussion of the equity aspects of indirect taxation. Thus, while an indirect tax applicable to all output would be equivalent to a general, flat-rate income tax applicable to all factor payments, an indirect tax applying only to all consumption will differ from an income 


\section{SUMMARY}

tax. Not only will final product prices be affected, but the incomes of resources specialized to the production of taxed products will also be changed. The precise effects of substituting partial indirect taxes for general taxes depend on the production functions of industries producing items subject to tax and of nontaxed industries, as well as on the respective elasticities of demand for the outputs of the taxed and untaxed industries, and on the respective elasticities of supply of productive resources to the taxed and untaxed industries. It may be that resourceincome gains and losses will be randomly distributed by income classes. In such a case, the shift would be neutral, in aggregative terms, on the income sources side. But only in this case is the effect on the structure of prices of final output the proper criterion for appraising the over-all distributional impact of the shift.

With respect to the use of broad-based indirect taxes, Eldridge notes that substitution of a value-added tax of the income variety for part of the income tax would involve giving up elements of progression for an essentially proportional tax; and a shift to a general consumption taxeither one on retail sales or a value-added tax of the "consumption" variety-would tend to make the tax burden distribution regressive to the extent that the proportion of income saved increases as income levels rise.

Eldridge finds that elimination of the present bias against corporate equity investment is desirable both in terms of equity and in terms of economic neutrality. Although substituting a value-added tax for the corporate profits tax would be a step toward neutrality, the substitution would accentuate problems of integrating business and personal taxes so as to achieve an equitable distribution of the total burden among individuals. A superior approach to the problem, in Eldridge's view, involves modifying the individual income tax and concentrating corporate tax reform efforts on integration of the corporate and individual taxes.

Alternative criteria yield different conclusions about vertical equity under various tax structures. If "Fisher" income is viewed as the appropriate tax base, general indirect taxes are not regressive. The choice depends on whether one accepts Fisher's view that all economic benefits stem from consumption. In this case, equating taxable capacity with consumption is appropriate. But if one believes that saving as well as consumption yields current satisfaction, the accretion concept of taxable income is superior.

Eldridge rejects the argument that sales taxes can be made as progressive (with respect to income) as income taxes by proper use of ex- 


\section{SUMMARY}

emptions. This argument, he points out, rests on the assumption that burdens of indirect taxes fall entirely on persons as consumers, and not at all on producers, and that these burden distributions can be accurately inferred from budget studies of consumer units. Moreover, even if the assumptions were valid, the standards of horizontal equity would not be met. There is considerable evidence that sales taxes bear more heavily on large families than on small families within every income group. These burdens also vary with racial, ethnic, and other family characteristics such as rural or urban residence.

Eldridge notes that greater use of federal indirect taxes is often urged as a means of reaching persons who avoid income taxes by taking advantage of the differential provisions in the law, or who evade their income tax liabilities. But realistically, he holds, any indirect tax would open up new avenues of avoidance and evasion.

Taking up problems of administration and compliance, Eldridge finds that neither income taxes nor indirect taxes, if they are broadly based and produce substantial revenues, involve prohibitive costs of compliance and administration. However, costs of administration and compliance increase significantly with departures from generality. Since a shift toward indirect taxes would undoubtedly involve significant departures from generality of coverage, it would create significant problems of administration and compliance. Many of the problems would involve definition, and in this sense would parallel those arising from income taxation. Eldridge concludes that a shift to indirect taxes holds little prospect of reducing compliance and administration costs. In this respect he sees more promise in a move toward a low-rate income tax applicable to adjusted gross income without exemptions.

Eldridge does not find that a substantial shift by the federal government toward indirect taxation would hamper the ability of state and local governments to finance their growing needs. However, such a shift would lessen the significance of tax deductibility as an intergovernmental tax-coordinating device.

In his discussion of the Eldridge paper, Brazer argues that, in practice, horizontal equity is impossible under a system of selective excises, and that a truly general sales tax (with capital goods taxable), while it could provide horizontal equity, is not feasible. Since it is also impossible to achieve a truly general personal income tax, the choice between the two taxes on horizontal equity grounds should rest on the political feasibility of obtaining the more general tax. In terms of vertical equity, however, Brazer finds income taxation clearly preferable to sales taxation. He 
therefore concludes that the best policy is to concentrate on perfecting the coverage of the income tax.

On the matter of intergovernmental fiscal relations, Brazer discounts the argument that the federal government should leave the indirect tax field to states and localities. Rather he sees some positive administrative advantages in multilevel use of the same taxes.

Welch's discussion emphasizes that sales taxes in practice are never truly general. Problems of administration as well as consideration of other tax criteria result in partial levies, often with little underlying rationale. Attempted enactment of a value-added tax would probably encounter the same obstacles. Welch does not believe that a shift to more federal indirect taxation would enhance intergovernmental fiscal cooperation.

Most of the general discussion of the Eldridge paper focused on equity problems. Eldridge had criticized the growing literature based on the argument that a feasible excise-tax system could have substantial progression built into it. Proponents argue that such a system of excises would catch spending out of income that now escapes tax, thereby promoting horizontal equity and enforceable progression. For example, excise taxes on consumption would reach those who finance additional consumption out of lightly taxed capital gains, and better yet, it would get at those who manage to avoid or evade the income tax completely.

The desirability of such an approach was, not surprisingly, a matter of active debate. Several discussants argued that enactment of a truly progressive system of excises is not feasible. Some were more optimistic than others about prospects for broadening the coverage of the individual income tax in the relatively near future, and did not consider the imposition of excises for the sake of broader coverage to be of much value even if the intended progression could be achieved. Others pointed out that major avenues of escape from income taxes could not be closed by commodity taxes because the latter would not bear on substantial elements of income (particularly investment income and capital gains) that are never disgorged on consumption. Nor would important types of nonmoney income, such as imputed rent of owner-occupied houses, food and fuel produced on farms, and implicit interest, be covered by excise taxes. And even though it was granted that the partial coverage of the income tax does create "excise-like" effects, it was argued strenuously that the problem of fractional coverage would be much more serious under any conceivable system of federal excise taxation. A major concern would be the exemption of most services, which, as Brazer had pointed out in his 
discussion paper, the states have never been able to include in their salestax bases.

The issue of the effects of excises on prices of productive resources (or income sources) arose again, and in view of the importance of this question, one of the participants lamented the lack of empirical work on this subject. Basically, the question revolves around the ease with which resources can be shifted from one use to another. Harberger's assumption of constant costs entirely eliminates any effects on relative factor prices from the analysis. Eldridge, on the other hand, stresses the possible importance of induced changes in factor prices.

One discussant offered the empirical proposition that indirect taxes generally have a proportional incidence. On the product prices side, he argued, it is almost impossible to devise an excise tax so as to hit only purchases of high-income groups. For example, a tax on toiletries applies to baby oil, and a tax on new automobiles raises used-car prices. On the income side, he asserted, the tax reduces factor prices about proportionately, and incidence will be diffused more or less equally among all resource owners. Thus, incidence is approximately proportional no matter which way the tax is shifted.

Along the same lines, an argument was advanced that only if excise taxes were levied on a significant proportion of the national product would they be likely to have material effects on relative factor prices. Apparently the supposition here is that "small" taxes induce only minor displacements of resources and hence cannot produce more than minor changes in relative resource earnings.

Noting that the available range of alternatives includes other taxes, one discussant urged that serious consideration be given to enacting more severe inheritance tax laws, especially in the case of inheritances of younger generations. He argued that this would promote economic equality in the most desirable way - by reducing the unjustified advantages of those born to wealth. Somewhat along the same line, he contended that more attention should be given to Henry George's property taxation proposals designed to confiscate unearned property rents. Properly levied, such taxes would have no effect whatever on economic incentives, and they would greatly reduce economic inequality.

\section{European Experience}

Eckstein's paper compares the relative reliance on direct and indirect taxes in the U.S., France, Germany, Italy, Japan, and the United Kingdom. After noting the conceptual ambiguities in any distinction between 
direct and indirect taxes, he defines direct taxes as levies on income, estates and gifts, personal capital, and social security contributions paid by the employee. All other levies are treated as indirect taxes.

On this basis, when receipts of all levels of government are included, the ratio of direct taxes to total taxes in the U.S. is higher than in the other countries considered. But the difference is much less dramatic than is generally contended. Moreover, with the U.S. income tax cut enacted, the ratio of U.S. direct taxes to GNP would be comparable to the ratio in Germany and the United Kingdom.

Eckstein contends that the usual comparisons of the U.S. with other countries are misleading because they generally consider only central government revenues, include only income taxes in the direct tax category, and relate direct taxes only to total tax revenues rather than to GNP, the more relevant measure of impact. He also stressed the significance of the comparative burdens of particular taxes, as contrasted to comparison of relative dependence on various types of taxes.

Eckstein calls particular attention to statistics indicating that in the countries under consideration, the rate of nonresidential investment as a percentage of GNP is closely correlated with the percentage rate of expansion of GNP during the 1950's. But, he holds, the impact of tax policy on the rate of investment is not clear.

According to Eckstein, substitution of value-added taxation for the corporation income tax would reduce the tax burden on high-profit corporations and raise the burden on low-profit corporations. This, he holds, would produce a more efficient allocation of capital. Further, such a change would lead to substitution of capital for labor, would bring into the tax base presently exempt organizations such as cooperatives, and would reduce tax-caused distortions in decision making. He also foresees an increased rate of business saving, reduced built-in flexibility of the revenue system, and an expansion of exports following such a change.

Neumark, in his comment, contends that Eckstein's analysis rests on too ambiguous a distinction between direct and indirect taxes. Furthermore, he argues that the alleged regressiveness of indirect taxes should be appraised in light of the progressive expenditures they finance.

Neumark holds that it is not the relatively greater use of indirect taxes that accounts for the favorable growth experience of countries examined by Eckstein but rather their use of high tax rates, together with selective tax abatements designed to direct activity into desired channels.

Smith, in his discussion paper, holds that the technical features of various tax systems are more important sources of differences of tax im- 
pact than are variations of relative emphasis on broad categories of types of taxes. Thus, distinctions between direct and indirect taxes may be meaningless or misleading in consideration of the impact of taxes on growth, even if such distinctions are useful in other contexts.

In the general discussion, much attention was given to the implication of Eckstein's observation that the correlation between growth rates and rates of nonresidential investment was extremely high during the 1950's for the countries he considered. Although Eckstein had declined to interpret the precise meaning of this correlation, he had concluded that "a high rate of growth over a considerable interval is, with little doubt, always associated with a high rate of nonresidential investment."

Discussion of this point was confined to the notion that the high rate of investment is the cause of the high rates of growth observed. This view, of course, conflicts with the one set forth by Harberger in his appraisal of the implications of accelerated investment for economic growth. The question at stake was of paramount importance for the conference. The case for more indirect taxation rests heavily on the notion that the rate of investment will be increased and that the rate of growth is closely associated with the rate of investment.

Out of the probing discussion of Eckstein's argument, two possibly significant empirical criticisms emerged. The first was that if the sample of countries were enlarged, and particularly if Latin American countries were included, the relationship would become much less clear, and might even disappear. Eckstein's paper, it was contended, happens to single out countries where industrial investment was, due to peculiar circumstances of time and place, the crucial element in the growth process.

Second, the argument was advanced that if investment figures were corrected for differences in the prices of investment goods relative to all other prices, country by country, the apparent differences among rates of capital formation would diminish or disappear, since the countries with high ratios of investment to GNP were also the countries where investment goods had higher relative prices. Thus, the raw figures cited by Eckstein were alleged to give a somewhat misleading impression of differences in ratios of increase of real capital stock to output.

A further criticism was that Eckstein had formulated the problem incorrectly. According to this view, the relation of investment spending to gross national product is not relevant for assessing the effects of increased capital formation on the rate of economic growth. The correct relationship is that between the percentage rate of growth of the capital stock and the percentage rate of growth of GNP. 
It was not, of course, possible to settle all such questions on the spot. Other factors, including low capital-labor ratios in war-devastated areas, rapid expansion of labor forces, and the maintenance of high aggregate demand were cited as important forces working for European economic growth. But there was great reluctance to support the notion that indirect taxes provided a real key to the puzzle. The evidence just does not seem to warrant such a conclusion. Rather, stress was put on the role of tax concessions for investment, particularly investment in industrial capital. In postwar years such concessions were made on both direct and indirect taxes.

This view, however, raised the perplexing problem of Britain's slow growth. Certainly Britain had granted heavy tax favors to investment. Eckstein's paper had dismissed rather casually the idea that Britain's problem was weak entrepreneurship. But strong arguments were raised in favor of this thesis during the discussion. It was asserted that unimaginative investment decisions had become ritual and that Britain's growth rate had thereby been made the captive of tradition. Furthermore, it was argued that the capital shortages Eckstein's paper referred to were illusory-that in fact business saving provided a plentiful supply of finance.

As Due pointed out in his summary of the issues, a clear distinction must be made between the potential and the actual pace of economic growth. At various points in the conference, participants were critical of analyses which assumed full employment. With reference to the United States, it was pointed out that perhaps 5 per cent could be added to GNP simply by moving to a satisfactory rate of resource utilization. Several persons saw the main impediment to full employment as the federal government's unwillingness to run a sufficiently large deficit. Under these conditions, any substitution of direct for indirect taxes that raised the rate of saving would further complicate the unemployment problem. Furthermore, it was pointed out that since the imposition of indirect taxes would result in at least some markup of prices (including tax), the level of spending needed to produce full employment would increase. The European experience, which occurred in a setting of generally buoyant aggregate demand, was therefore held to be of doubtful relevance in considerations of U.S. tax policy.

\section{Conclusion}

The debate over the relative merits of direct and indirect taxes is an old one. No two-day conference of experts can be expected to lay even the 
theoretical issues to rest, much less to resolve differing value judgments. Since few issues of substance were unanimously agreed upon by the conferees, it is hazardous to attempt to draw out a consensus. But certainly the proceedings of the conference, viewed in their entirety, provide little support for a major move in the direction of commodity taxation and away from income taxation.

It was generally agreed that the distinction between direct and indirect taxation is ambiguous, and that the specific features of taxes are likely to be more important than superficial forms. The consensus seemed to be that income taxation, imperfect as it is in practice, lends itself better to keeping the welfare costs of taxes to a minimum, while permitting considerably more latitude in adjusting the progressiveness of the tax system.

On matters of administration and compliance, there seemed to be general agreement that indirect taxes are not superior to direct taxes, and there was some feeling that further inroads of the federal government into the indirect tax field would arouse opposition from state and local governments which rely heavily on such levies.

It seemed generally agreed that substitution of a value-added tax for the corporation income tax would lead to an improvement of the balanceof-payments position of this country, but few felt that the improvement would be more than minor. From the review of foreign experience, considerable agreement emerged that the differences between U.S. and European tax systems, with respect to relative reliance on indirect taxation, have usually been overemphasized, and that the influence of these differences on rates of economic growth is hard to detect. Rather, emphasis was given to the more specific features of taxes, direct or indirect, that provide a special incentive for capital formation. Furthermore, the importance of additional capital formation in the growth process was questioned. And insofar as more indirect taxation in this country might tend to raise the rate of saving, fear was expressed that the result might be greater unemployment.

It is hard, then, to find much support for more reliance on indirect taxation in the record of this conference, even though some participants came, and left, with a disposition toward this view. 